\title{
Effect of Planting Media and Different Concentration of Wheat Grass Juice (Triticum aestivum L.) on Anemic Male Mice (Mus musculus L.) Leukocytes
}

\author{
Elsa Yuniarti ${ }^{1 *}$ Afifatul Achyar ${ }^{1}$ Syovia Amimi ${ }^{1}$ \\ ${ }^{1}$ Dept. of Biology, Faculty of Mathematics and Science (FMIPA), Universitas Negeri Padang, Padang, Indonesia \\ *Corresponding author. Email: elsayuniarti@gmail.com
}

\begin{abstract}
Iron deficiency can cause anemia. Changes in iron status in anemia can affect the immune system, making infection easy. When the number of infections increases, efforts made to overcome anemia are one of them by consuming wheat grass containing iron. This study was an experiment with factorial complete randomized design (CRD). The number of samples was 40 male mice aged 8-10 weeks, weighing 20-30 g which were grouped into 8 treatment groups and each consisted 5 of mice. Treatment K1: not given wheat grass juice (control), K2: not given juice wheat grass after induction of $\mathrm{NaNO}_{2}$ (anemia treatment), P1T: group given $50 \%$ wheat grass juice which was planted with soil after anemic treatment. P2T: a group that was given wheat grass juice with a concentration of $75 \%$ which was planted with soil after anemic treatment and P3T: a group that was given wheat grass juice with a concentration of $75 \%$ planted with soil after anemic treatment. P1H: groups given 50\% wheat grass juice planted hydroponically after anemic treatment. $\mathrm{P} 2 \mathrm{H}$ : a group given $75 \%$ wheat grass juice which was planted hydroponically after anemic treatment. $\mathrm{P} 3 \mathrm{H}$ : group given $100 \%$ wheat grass juice which is planted hydroponically after anemic treatment. Taking blood was taken before and after giving wheat grass juice for 14 days through the tip of the tail of mice. Data were analyzed using ANOVA followed by DMRT follow-up with a level of 5\%. The results showed that the planting medium had no effect on male leukocytes where $F_{\text {count }}>F_{\text {table. }}$. Giving wheat grass juice with different concentrations has an effect on

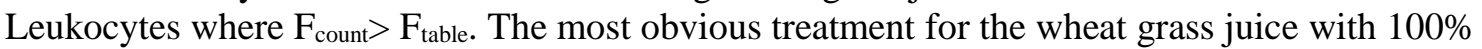
concentration.
\end{abstract}

Keywords: Triticum aestivum, Leukocytes, Anemic

\section{INTRODUCTION}

Anemia is a condition where a person has a lower number of erythrocytes than usual, erythrocytes or the amount of hemoglobin in erythrocytes drops below normal, so that in a low state can prevent body cells to get enough oxygen [1]. Lack of hemoglobin in the blood can be caused by a variety of factors, but more than $50 \%$ of the most cases of anemia throughout the world are directly caused by lack of iron $(\mathrm{Fe})$ intake. The lack of hemoglobin in the blood can cause symptoms of lethargy, fatigue, forgetfulness, and can reduce body resistance and easily get infected by viruses and bacteria that cause disease [2].

Leukocytes (white blood cells) also play a role as an active unit and the body's defense system, leukocytes as the body's defense against unknown objects that will enter the body, leukocytes maintain that the body is not easily exposed to various infections or antigens that are unknown to the body [3]. Changes in iron status in the body can affect immune responses in various ways, one of which will be an infection. When infection occurs leukocytes will play a role and increase the amount in the body because after being formed, leukocyte cells quickly provide the necessary defense in large quantities for the immune system in the body which plays a role in strengthening the resistance to fight the infection [4].

Efforts can be made to reduce the risk of developing iron deficiency anemia by consuming wheat grass. Wheat grass (Triticum aestivum L.) is a plant from the family Gramina which can be consumed when the age of the plant steps on the seventh day since planting [5]. Wheat grass (Triticum aestivum L.) which has been made into juice contains many vitamins, minerals, enzymes and a source of food that is rich in chlorophyll [6]. One mineral content of wheat grass is iron in every 100 grams of wheat grass containing iron as much as $126 \mathrm{mg}$ higher than other green vegetables such as spinach on average only $7 \mathrm{mg}$ every 100 grams [7].

Wheat grass can be planted directly on the ground or using hydroponic methods. Planting wheat grass using the hydroponic method has many advantages, one of which is the cleanliness that is maintained because it is not exposed to the soil directly, so that the wheat grass will be cleaner because it will be consumed directly by juicing. However, the planting media used in hydroponic methods such as fuel husk, nutrient content is not as complex as the nutrients contained in the soil media. Most uses of the 
hydroponic method are added by using Nutrient Mix which contains macro and micro nutrients [8]..

\section{MATERIALS AND METHODS}

\subsection{The Research Population}

This type of research is experimental research. The design used was Factorial Completely Randomized Design, carried out in January-February 2019 at the Biology Laboratory of FMIPA UNP.

The population in the study was 48 male mice (Mus musculus L.) aged 8-10 weeks with a weight of 20-30 grams. The sample in this study was 40 male mice (Mus musculus $\mathrm{L}$.) randomly selected from the population

\subsection{Mice of Anemia treatment}

Anemia treatment is done by giving Sodium Nitrite $\left(\mathrm{NaNO}_{2}\right)$ to mice. Sodium Nitrite provided that LD50 on average from Sodium Nitrite orally in mice is $250 \mathrm{mg} / \mathrm{kg}$ body weight. In this study, the body weight of mice was 20 $\mathrm{g}$, so the level of sodium nitrite for each of them was $5 \mathrm{mg}$. Effective pathological anemia treatment is $\operatorname{LD} 50=1 / 2 \times 5$ $\mathrm{mg}=2.5 \mathrm{mg}$. So, the dose used in eachof them is $2.5 \mathrm{mg}$ which is dissolved in $1 \mathrm{~mL}$ of distilled water. Sodium Nitrite is given as $0.1 \mathrm{ml} / 10 \mathrm{~g} \mathrm{BB} /$ day, so that the sodium nitrite is fed to the mice as much as $0.2 \mathrm{ml}$.

\subsection{Animal Experiment}

Preparation of Test Animals, mice were adapted for 7 days at room temperature before being given treatment. Before adaptation, mice were given feed in the form of pellets and PDAM water. Mice are then divided into 8 groups, that is K1: not given wheat grass juice and not treated with anemia (control)

K2: not given wheat grass juice after anemia treatment (anemia control)

P1T: given $0.5 \mathrm{~mL}$ wheat grass juice with a concentration of $50 \%$ which was planted on the ground after anemic treatment.

P2T: given $0.5 \mathrm{~mL}$ wheat grass juice with a concentration of $75 \%$ which was planted on the ground after anemia treatment.

P3T: given $0.5 \mathrm{~mL}$ wheat grass juice with $100 \%$ concentration planted with soil after anemia treatment.

$\mathrm{P} 1 \mathrm{H}$ : given $0.5 \mathrm{~mL}$ wheat grass juice with a concentration of $50 \%$ which is planted with fuel husks after anemia treatment.

$\mathrm{P} 2 \mathrm{H}$ : was given $0.5 \mathrm{~mL}$ wheat grass juice with a concentration of $75 \%$ which was planted with fuel husks after anemic treatment.
$\mathrm{P} 3 \mathrm{H}$ : given $0.5 \mathrm{~mL}$ wheat grass juice with $100 \%$ concentration planted with fuel husks after anemia treatment.

Planting of wheat grass with soil media, wheat grass seeds soaked with water for \pm 6 hours to accelerate germination. The soaked seeds are then drained and then rinsed with clean water and placed into a polybag that has been filled with soil and placed in the sun. Planting wheat grass with fuel husk media, wheat grass seeds that have been germinated are put into the basket and covered with plastic so that the roots grow quickly. The container used for planting is two trays. The first tray is a tray with no holes as a container to accommodate the excess hydroponic nutrition provided, and the second tray is a hollow tray with the base covered with tissue. Perforated tray that has been covered with tissue and sprinkled with fuel husk as a planting medium. After that, the container containing fuel husks was then planted with wheat grass seeds that had germinated. Spray AB Mix solution with a sprayer to keep the seeds wet. Cover the tray with black plastic or cloth so that the wheat grass seeds are not exposed to direct sunlight. This treatment aims to make the growth of wheat grass faster.Making wheat grass juice, weighed the wheat grass as much as 100 grams, washed. Cut wheat grass into small pieces and then blend. Separate the pulp by filtering it using gauze. Once filtered, wheat grass juice obtained is wheat grass juice with a concentration of $100 \%$. Make dilution of wheat grass juice into two different concentrations of $75 \%$ and $50 \%$. Prepare gavage for the process of giving wheat grass extract to mice at a dose of $0.5 \mathrm{~mL}$ for 2 weeks.

Leukocyte measurements are carried out by cutting the tip of the tail of the mouse using surgical scissors. Blood from the tail of mice is released slowly by pressing the base of the tail, then sorted to the tip of the tail. The blood is sucked using a leukocyte thoma pipette up to 0.5. Turk diluent solutions are sucked with thoma pipettes until number 11. A $1 / 20$ dilution occurs. The two ends of the pipette are closed using the thumb and middle finger, the shaking is done by going back and forth. 1-2 drops of liquid in the thoma pipette are removed and discarded, then the tip of next droplet of thoma pipette is placed on one side of the counting chamber which has a cover glass and paper sheet on the other side. put on the microscope. Leukocytes in the 4 rooms, W line are calculated. Calculations start from the left in a zig-zag. To avoid incorrect calculations, the leukocytes that are in the left and top of the W line are counted as leukocytes in the counting chamber. The number of leukocytes / $\mathrm{mm} 3$ in blood can be calculated using the formula (N / 0.4) x 20 or $\mathrm{N} \times 50 \mu \mathrm{L}$. indormation: $\mathrm{N}=$ number of leukocyte cells in 4 calculated chambers, $0.4=$ volume of small cells and 20 $=$ dilutions.

The data obtained were analyzed for variance or analysis of variants (ANOVA) from this analysis. It will be known whether or not there is a treatment effect on the dependent variable, if $F_{\text {count }}>F_{\text {table }}$ then proceed with DMRT test with a significant difference of $5 \%$. 


\section{RESULT AND DISCUSSION}

Paired Comparation test results of paired leukocytes male mice with anemia condition with male leukocytes after being given wheat grass juice can be seen in table 1 .

The data obtained were analyzed for variance or analysis of variants (ANOVA) from this analysis. It will be known whether or not there is a treatment effect on the dependent variable, if $\mathrm{F}_{\text {count }}>\mathrm{F}_{\text {table }}$ then proceed with DMRT test with a significant difference of $5 \%$.

Table 1. Paired Comparation test of anemic male mice Leukocyte with male mice leukocytes after being given wheat grass juice

\begin{tabular}{|c|c|c|c|}
\hline \multirow[t]{2}{*}{ Group } & \multicolumn{2}{|c|}{$\begin{array}{l}\text { Average Number of Leukocytes } \\
\text { Male Mice } 103 / \mathrm{mm}^{3}\end{array}$} & \multirow[t]{2}{*}{$\begin{array}{l}\text { Sig. } \\
(2 \text {-tailed })^{\mathrm{a}}\end{array}$} \\
\hline & Preetest & Posttest & \\
\hline $\mathrm{K} 1^{\mathrm{d}}$ & 4,83 & 5,02 & \multirow[t]{8}{*}{0,007} \\
\hline $\mathrm{K} 2^{\mathrm{e}}$ & 7,04 & 7,10 & \\
\hline $\mathrm{P} 1 \mathrm{~T}^{\mathrm{b}, \mathrm{f}}$ & 6,15 & 5,10 & \\
\hline $\mathrm{P} 2 \mathrm{~T}^{\mathrm{b}, \mathrm{g}}$ & 6,63 & 4,17 & \\
\hline $\mathrm{P} 3 \mathrm{~T}^{\mathrm{b}, \mathrm{h}}$ & 6,56 & 4,06 & \\
\hline $\mathrm{P} 1 \mathrm{H}^{\mathrm{c}, \mathrm{f}}$ & 7,41 & 5,36 & \\
\hline $\mathrm{P} 2 \mathrm{H}^{\mathrm{c}, \mathrm{g}}$ & 6,89 & 4,32 & \\
\hline $\mathrm{P} 3 \mathrm{H}^{\mathrm{c}, \mathrm{h}}$ & 7,11 & 4,12 & \\
\hline A. & \multicolumn{3}{|c|}{ a significant difference. } \\
\hline B. & \multicolumn{3}{|l|}{${ }^{\mathrm{b}} \mathrm{T}$ (soil). } \\
\hline C. & \multicolumn{3}{|c|}{${ }^{\mathrm{c}} \mathrm{H}$ (hydroponics). } \\
\hline D. & \multicolumn{3}{|c|}{${ }^{\mathrm{d}} \mathrm{KI}$ (Normal Control). } \\
\hline E. & \multicolumn{3}{|c|}{${ }^{\mathrm{e}} \mathrm{K} 2$ (Control Anemia). } \\
\hline F. & \multicolumn{3}{|c|}{${ }^{\mathrm{f}} \mathrm{P} 1$ (50\% Wheat Grass Juice). } \\
\hline G. & \multicolumn{3}{|c|}{${ }^{\mathrm{g}}$ P2 (75\% Wheat Grass Juice). } \\
\hline H. & \multicolumn{3}{|c|}{${ }^{\text {h }}$ P3 (100\% Wheat Grass Juice). } \\
\hline
\end{tabular}

After the Paired Comparation Test in Table 1, Sig. (2tailed) $<0.05$ which is $0.007<0.05$, meaning that the number of leukocytes before being given wheat grass juice (anemia condition) different significantly from the number of leukocytes after being given wheat grass juice.

Based on Table 1, the number of leukocytes of male mice before and after treatment showed that the difference in decrease the average number of leukocytes in anemic condition (induced by $\mathrm{NaNO}_{2}$ ) in high leukocytes with an average leukocyte count after being given the highest treatment of grass juice. the highest on the soil planting media is P3T (100\% wheat grass juice) which is $2.50 \times 103$ $/ \mathrm{mm}^{3}$, P2T (75\% wheat grass juice) which is $1.05 \times 103 /$ $\mathrm{mm}^{3}$ and P1T (concentration of 50\% wheat grass juice). The difference in the decrease in the average number of leukocytes in the hydroponic growing media respectively from the highest to the lowest was $\mathrm{P} 3 \mathrm{H}$, which was $2.99 \times 103 / \mathrm{mm}^{3}, \mathrm{P} 2 \mathrm{H}$ which was $2.57 \times 103 / \mathrm{mm} 3$ and $\mathrm{P} 1 \mathrm{H}$ which was $2.05 \times 103 / \mathrm{mm}^{3}$. While the control group (K1) did not experience a decrease in the average number of leukocytes but experienced a rise of only $0.19 \times 103 /$ $\mathrm{mm}^{3}$ and anemia control (K2) was only $0.06 \times 103 / \mathrm{mm}^{3}$.
Table 2. ANOVA test results the effect of wheat grass juice (Triticum aestivum L.) on anemic male mice (Mus musculus L.) leukocytes.

\begin{tabular}{lll}
\hline Factor & $\mathrm{F}_{\text {count }}$ & $\mathrm{F}_{\text {tabel }}$ \\
\hline A (Planting Media) & 0,209 & 2,62 \\
B (Wheat Grass Juice Concentration ) & 4,331 & \\
\hline
\end{tabular}

Based on Table 2, factor A in the form of planting media from wheat grass and factor B is the treatment of grains of wheat grass juice of various concentrations, for factor A after ANOVA analysis was obtained in Table 6 that factor $A$ had no effect on the number of male leukocytes anemia due to $\mathrm{F}_{\text {count }}<\mathrm{F}_{\text {table }}$ at level $5 \%, \mathrm{~F}_{\text {count }}$ factor $\mathrm{A}$ is 0.209 while $\mathrm{F}_{\text {table }}$ is 2.62 at level 5\%, so DMRT further testing is not carried out.

The results of ANOVA analysis for factor B are $\mathrm{F}_{\text {count }}$ of 4.331 and $F_{\text {table }}$ is 2.62. This means that $F_{\text {count }}>F_{\text {table }}$ shows that factor $\mathrm{B}$ in the form of wheat grass juice treatment is significantly different so that the treatment of wheat grass juice has an effect on the number of male mice leukocytes. Furthermore, it is necessary to do DMRT further testing at a 5\% level to find out whether there are differences in each treatment.

Table 3. Summary data of the results of the DMRT Leukocyte Male Mice test at Different Concentrations After given the wheat Grass.

\begin{tabular}{cc}
\hline Treatment & Average Leukocyte Amount $\left(10^{3} / \mathrm{mm}^{3}\right)^{\mathrm{a}}$ \\
\hline P1 $(50 \%)^{\mathrm{b}}$ & $5.23^{\mathrm{b}}$ \\
P2 $(75 \%)^{\mathrm{c}}$ & $4.25^{\mathrm{a}}$ \\
P3 $(100 \%)^{\mathrm{d}} \quad 4.10^{\mathrm{a}}$ \\
\hline I. $\quad{ }^{\mathrm{a}}$ Numbers followed by the same letters show no \\
significant difference in the DMRT test at the 5\% \\
level. \\
J. $\quad{ }^{\mathrm{b}} 50 \%$ Wheat Grass Juice. \\
K. $\quad{ }^{\mathrm{c}} 75 \%$ Wheat Grass Juice. \\
L. $\quad{ }^{\mathrm{d}} 100 \%$ Wheat Grass Juice.
\end{tabular}

Based on the summary of the DMRT test results in Table 3 , it can be seen that there were significant differences in each treatment of wheat grass juice on the decrease in the number of male leukocytes in anemia, the highest decrease in the number of male leukocytes in P3 treatment with $100 \%$ concentration of wheat grass juice. According [9], research on giving wheat grass juice with a concentration of $75 \%$ can increase hemoglobin.

This decrease in leukocyte count is due to the chlorophyll content found in wheat grass. Chlorophyll is an active component in wheat grass extract. Chlorophyll content found in wheat grass can repair damaged cells and inhibit the metabolic activity of carcinogens. The number of male leukocytes increased during sodium nitritegiven in the form of chemicals and carcinogens for the body, so wheat grass chlorophyll was able to reduce the number of male mice leukocytes in anemic condition [8].

Chlorophyll can function as an antioxidant [10]. Chlorophyll and its derivatives can have antimulgenic, anticarcinogenic functions, reduce serum, reduce triglycerides, and reduce constipation [11]. Wheat grass 
has been shown to have anti-cancer activity, antioxidant activity, and generally helps blood flow, digestion and body detoxification [12]. Research on evaluating the clinical efficacy of wheat grass tablets as a supportive treatment in leukemic patients, wheat grass tablets containing chlorophyll were also able to reduce the number of white blood cells [13]. In patients who consume wheat grass juice during chemotherapy the level of oxidative stress is lower so that wheat grass juice can be used as an antioxidant tablet in reducing oxidative stress [14].

Wheat grass contains enzymatic and non-enzymatic antioxidants and shows higher antioxidant activity than other fruits and vegetables, so wheat grass can be used as an antioxidant supplement in chronic diseases [15]. Wheat grass contains enzymatic antioxidants in the form of peroxidase, superoktsida dismutase and cytochrome [16]. Non-enzymatic antioxidant components in wheat grass consist of chlorophyll, ascorbic acid and beta carotene [17].

Although the soil planting media and fuel husk (hydroponics) of wheat grass have no effect on the number of leukocytes of male mice but, both planting media have

\section{CONCLUSION}

Based on the results of the study, it can be concluded that there is a significant difference in anemia of male leukocytes (Mus musculus L.) with leukocytes after being given wheat grass juice (Triticum aestivum L.). The juice of wheat grass (Triticum aestivum L.) grown with different media did not affect the leukocytes of male mice (Mus musculus L.) anemia. The concentration of wheat grass juice (Triticum aestivum L.) planted with different media had an effect on anemia male leukocytes (Mus musculus L.) and the most significant concentration of wheat grass juice treatment was $100 \%$.

Suggestions of this study the people need to try the benefits of wheat grass plants (Triticum aestivum L.) that can play a role in health.

\section{REFERENCES}

[1] Agarwal. N, JT. Prchl. 2009. Anemia of Chorionic Disease (Anemia of Inflamation). Acta Haematologica. 122 103-8.

[2] Masrizal. 2007. Anemia Difisiensibesi. Jurnal Kesehatan Masyarakat. 2 140-5.

[3] Guyton and Hall. 2014. Buku Teks Fisiologi kedokteran Ed.6. Jakarta: EGC Penerbit Buku Kedokteran.

[4] Cherayil, B. J. 2010. Iron and Immunity:Immunological Consequences of Iron Deficiency and Overload. NIH Public Accsess. 58 407-15.

[5] Wigmore, A. 2011. The Wheatgrass Book. United States: Avery Publishing.

[6] Dutta, A. K. and Wasim R. 2016. Wheatgrass a Perfect Food and Its Anti-Microbial Properties their respective advantages, soil planting media are well used without providing additional nutrients and are more economical because they can use existing humus around the environment while for hydroponics using $\mathrm{AB}$ mix nutrients make the plant more hygienic because it is not directly contaminated by the dirt contained in the soil.amounts. Contrariwise, Nisa's research(9) shows that the ability of endophytic bacteria to produce antimicrobial compounds is lower than that of plant hosts. This difference in results can be caused by several factors, one of them is the use of solvents to extract active compounds which are not appropriate. In this research, the solvent used was ethanol, which is polar. According to (11), the type of solvent was a factor that influences the concentration and type of compound to be extracted. The polarity of the solvent is an important thing that influences the antimicrobial activity. Therefore, further experiments need to be carried out using non-polar solvents

From The Different Solvent Extract. World Journalof Pharmacy and Pharmaceutical Sciences. 5 1818-28.

[7] Roshan, K., Rathore K. S., Goel, P. K., Naruka, S. S., Saurabh. 2016. Therapeutic Potential of Triticum aestivum Linn. (Wheat Grass or Green Blood Therapy) in the Treatment and Prevention of Chronic and Acute Diseases: An Overview. Pharmatutor. 4 19-27.

[8] Utama, H. S., Sani M. I., Arie I. 2006. Perancangan dan Implementasi Sistem Otomatisasi Pemeliharaan Tanaman Hidroponik. Jurnal Teknik Elektro. 8 1-4.

[9] Yuniart, E., L., Hasanah, L., Advinda, and P. M., Indika. 2019. Effect of whaet grass juice (Triticum aestivum L.) against the erythrocytes and hemoglobin in male mice (Mus musculus L.) anemia induced by sodium nitrite. Journal of Physics: Conference Series 1317012069.

[10] Fahey, J.W., Stephenson, K.K., Dinkova- Kostova, A.T., Egner, P.A., Kensler, T.W., and Talalay, P. 2005. Chlorophyll,chlorophyllin and related tetrapyrroles are significant inducers of mammalian phase 2 cytoprotective genes. Carcinogenesis. 6 1247-55.

[11] Hsu, C., Chao, P., Hu, S., Yang, C. 2013. The Antioxidant and Free Radical Scavenging Activities of Chlorophylls and Pheophytins. Food and Nutrition Sciences. 4 1-8.

[12] Payal, C., Davinder, K., Sunaina, Gurlaganjeet, K., Gagan, S., Amit, C., and Dhawan, R.D. 2015. A Review On Pharmacognosy and Pharmacological aspects. International Journal Of Phytopharmacology. 6 80-5. 
[13] Lansolanki, M.J.K., Bhaidpatel, L. 2015. Clinical Efficacy Evaluation of Wheat Grass Tablets as Supportive Treatment in Leukemia Patients. RJPBCS. 6 1451-4.

[14] Sharma, S., Shirvastav, B. R., Shirvastav, A. 2016. Effect of Wheat Grass Juice on Reduced Glutathione and Glutathione Related Enzymes in Lung Cancer Patiensts During Chemotherapy. World Journal of Pharmaceutical Research. 5 1608-15.

[15] Sharma, S., Shiravtav, V. K., Shirvastav, A.,Shirvastav, B. R. 2013. Therapeutic Potential of Wheat Grass (Triticum aestivum L.) for the Treatment of Chornic Diaseases. South Asian Journal of Experimental Biology. 3 308-13.

[16] Parit, S. B., Dawkar, V. V., Tanpure, S. R., Pai, S. R., Chougale, A. D. 2018. Nutritional Quality and Antioxidant Activity of Wheatgrass (Triticum aestivum) Unwrapby Proteome Profiling and DPPH and FRAP assays. Journal of Food Science. 0 1-13.

[17] Agrawal, A., Gupta, E., Chaturvedi, R. 2015. Determination of Minerals and Antioksidant Activities at Different Levels of Jointing Stage in Juice Wheat Gass-The Green Wonder. International Journal of Pure \& Applied Bioscience. 3 311-6. 